\title{
Association of Pesticide Exposure with Anemia in Women Farmers in Bandungan Village, Semarang District
}

\author{
Sri Kartini ${ }^{1}$, Onny Setiani ${ }^{2}$, Tri Joko ${ }^{2}$
}

\author{
${ }^{1}$ Students in the Environmental Health Master's Program at the Faculty of Public Health Diponegoro University, In donesia \\ ${ }^{2}$ Teaching Staff for Environmental Health Master's Program at the Faculty of Public Health Diponegoro University, \\ Indonesia
}

\begin{abstract}
One of the causes of anemia is the use of inappropriate pesticides. The body exposed to pesticides causes blood profile abnormalities because pesticides interfere with the organ of blood cell formation, and the immune system. Studies from all over the world have shown negative effects on health from pesticides commonly used in agricultural activities.The study aimed to analyze the correlation of pesticide exposure with the incidence of anemia in women farmers in the agricultural area of Bandungan Su-District, Semarang District. This research was observational type with cross sectional design. The sampling technique was nonprobability sampling with purposive sampling. The number of samples in this study were 50 women farmers. The results of this study that there were association between duration of pesticide spraying, the number and type ofpesticides used with anemia in women farmers in Bandungan Village, Semarang District. There were no association between cholinesterase level with anemia in women farmers in Bandungan Village, Semarang District. The conclusion of the research that there was association between pesticide exposure with anemia in women farmers in Bandungan Village, Semarang District.
\end{abstract}

Keywords—pesticides, women farmers, anemia, cholinesterase, blood profile.

\section{INTRODUCTION}

U.S. The Department of Health and Human Services of the National Institute of Health said that anemia wass a condition of blood disorders. In individuals who have anemia, the body does not have red blood cells (RBC) in sufficient quantities. RBC is one of the three main types of blood cells. RBC contains hemoglobin. Hemoglobin is a protein in red blood cells that carries oxygen. Types of anemia include iron deficiency anemia, pernicious anemia, aplastic anemia, hemolytic anemia.[1]

Risk factors for iron deficiency anemia are caused by age, unhealthy environment, family history and genetics, lifestyle habits, or gender.[2] In addition, health factors are also a risk factor for iron deficiency anemia. [3] One of the causes of anemia is the use of inappropriate pesticides. Bodies exposed to pesticides cause blood profile abnormalities because pesticides interfere with the organ of blood cell formation, and the immune system.[4] The highest anemia prevalence by region is found in South Asia, Central Africa and West Africa.[5] Studies from around the world have shown negative effects on health from pesticides commonly used in agricultural activities.[6]
Pesticide exposure can occur through 4 (four) main routes, namely oral or ingestion (through the mouth and digestive system), ocular (through the eye), dermal (through the skin), or inhalation (through the nose and respiratory system).[7]

The results of the preliminary study showed that farmers in Bandungan Subdistrict used the most pesticides from dinitroaniline $(70 \%)$, carbamate $(60 \%)$, and organophosphate (35\%) with successive formulations Kocide 45 WG, Antracol 70 WP, and Akron 500 EC. In addition there are also female farmers who participate in spraying plants using pesticides. The incomplete use of Personal Protective Equipment (PPE) also increases the potential for direct contact with pesticides .

The purpose of this study was to determine the relationship of pesticide exposure to the incidence of anemia in women farmers in the agricultural area of Bandungan Sub-District, Semarang District. The contribution of this study is to increase public understanding that exposure to contaminants in the environment, especially pesticides, can worsen health conditions including the incidence of anemia. So that the community can make efforts to prevent the incidence of anemia, especially related to exposure to pesticides. 


\section{METHOD}

The type of research used was observational analytic. The research design was cross sectional. Sampling was a nonprobability sampling approach. The sampling technique used was purposive sampling. The number of samples in this study were 50 women farmers. The method used for testing cholinesterase activity is kinetic photometric tests. The materials of this study were photometric TruCal U system, digital body scales, stature meter, digital tensimeter, questionnaire, spuit and bevel.

\section{RESULT AND DISCUSSION}

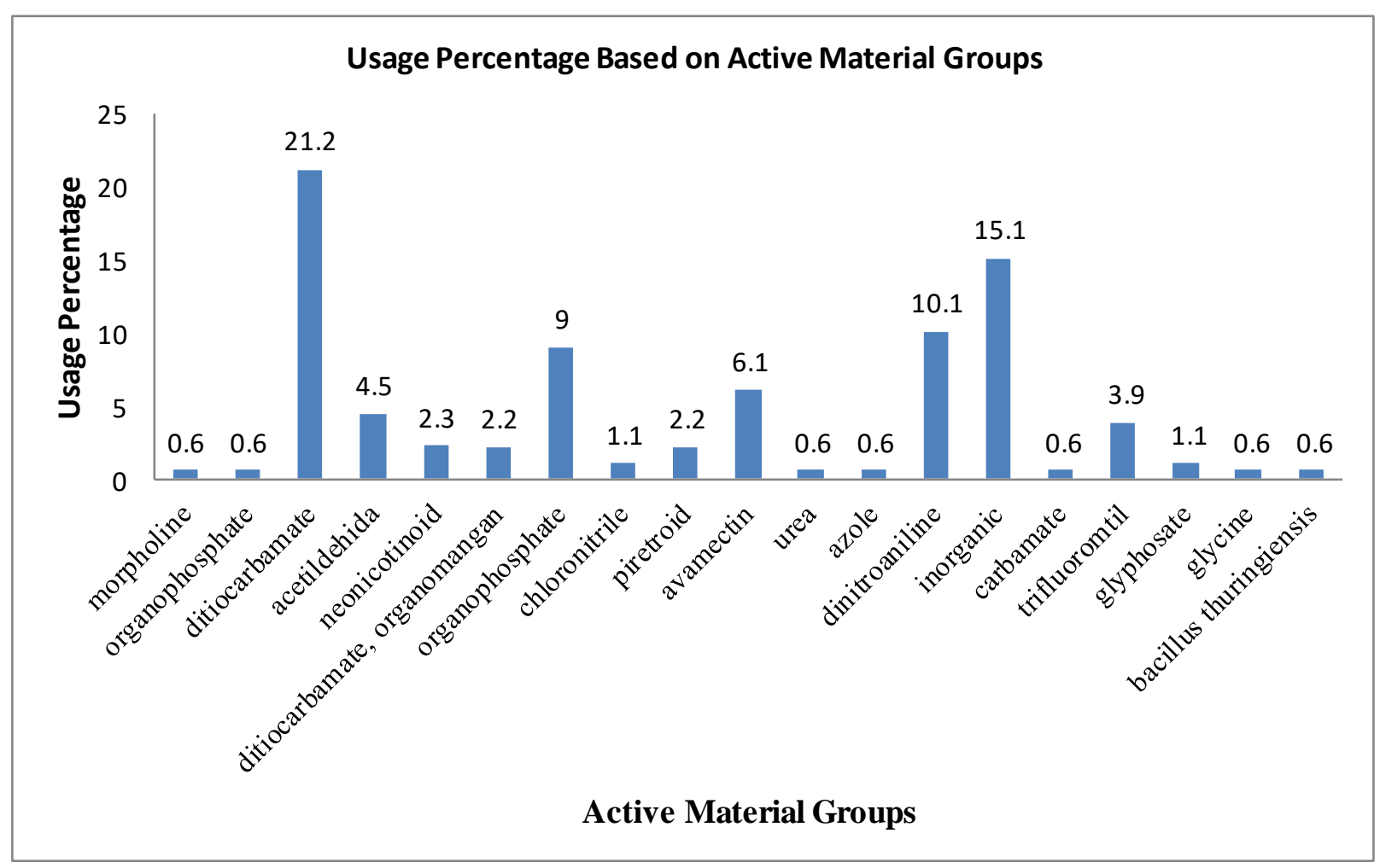

Fig.1: Usage Percentage Chart Based on Active Material Groups

In the figure 1 , the percentage of usage based on the highest active material group was the active material of ditiocarbamate which is $21.2 \%$. While the lowest use is morpholine, organophosphate, urea, azole, carbamate, glycine, Bacillus thuringiensis by $0.6 \%$.

Table 1: Recapitulation of Inferential Analysis Results

\begin{tabular}{|c|c|c|c|c|c|c|c|}
\hline \multirow{2}{*}{ No } & \multirow{2}{*}{$\begin{array}{c}\text { Independent } \\
\text { variable }\end{array}$} & \multirow{2}{*}{$\begin{array}{c}\text { Dependent } \\
\text { variable }\end{array}$} & \multirow{2}{*}{$p$} & \multirow{2}{*}{$\mathrm{RP}$} & \multicolumn{2}{|c|}{$95 \% \mathrm{CI}$} & \multirow{2}{*}{ Information } \\
\hline & & & & & Lower & Upper & \\
\hline \multirow{2}{*}{1} & \multirow{2}{*}{ Working period } & Anemia & 1,000 & 0,813 & 0,202 & 3,263 & Not significant \\
\hline & & Anemia & 0,077 & 0,325 & 0,101 & 1,042 & Not significant \\
\hline \multirow{2}{*}{2} & \multirow{2}{*}{$\begin{array}{l}\text { The duration of } \\
\text { pesticide spraying }\end{array}$} & Anemia & 0,198 & 0,290 & 0,062 & 1,352 & Not significant \\
\hline & & Anemia & 0,008 & 0,217 & 0,068 & 0,694 & Significant \\
\hline \multirow{2}{*}{3} & \multirow{2}{*}{$\begin{array}{l}\text { The number and } \\
\text { type of pesticides }\end{array}$} & Anemia & 0,033 & 0,171 & 0,037 & 0,787 & Significant \\
\hline & & Anemia & 0,260 & 0,500 & 0,202 & 1,239 & Not significant \\
\hline \multirow{2}{*}{4} & \multirow{2}{*}{$\begin{array}{l}\text { The frequency of } \\
\text { pesticide spraying }\end{array}$} & Anemia & 0,541 & 2,457 & 0,587 & 10,289 & Not significant \\
\hline & & Anemia & 0,527 & 1,843 & 0,669 & 5,076 & Not significant \\
\hline \multirow{2}{*}{5} & \multirow{2}{*}{$\begin{array}{l}\text { The cholinesterase } \\
\text { level }\end{array}$} & Anemia & 1,000 & 1,317 & 0,180 & 9,638 & Not significant \\
\hline & & Anemia & 1,000 & 1,207 & 0,322 & 4,532 & Not significant \\
\hline
\end{tabular}


Table 2 : Multivariate Analysis Results

\begin{tabular}{lcccccc}
\hline No & Variable & B & $p$ & Exp (B) & \multicolumn{2}{c}{$95 \%$ CI } \\
\cline { 6 - 7 } & & & & & Lower & Upper \\
\hline 1 & The number and type of pesticides & $-2,11$ & 0,021 & 0,121 & 0,02 & 0,723 \\
2 & The duration of pesticide spraying & $-2,064$ & 0,006 & 0,127 & 0,029 & 0,552 \\
\hline
\end{tabular}

Exposure to pesticides with heterogeneous chemical structures can cause different health effects. Short and medium term OP (organophosphate) exposure is mainly associated with liver damage and peripheral nerve disorders, while OS (organosulfur) exposure can cause kidney dysfunction and liver damage. Neurotoxicity resulting from exposure to $\mathrm{ON}$ (organonitrogen) after exposure to OP (organophosphate) in addition to the potential for liver damage and induced glucose changes. For comparison, the estimation results show that PYR (piretroid) may be very toxic in the case of low dose use.[8]

Research conducted by Richard P. Gallagher et al., In relation to the incidence of excessive leukemia found in farmers in British Columbia, this study showed an increased risk of death from aplastic anemia. Aplastic anemia has been reported after exposure to various pesticides, especially organochlorine compounds, such as lindane, DDT, chlordane, and heptachlor, as well as some organophosphate insecticides. Most of the reports in the literature are case reports, and epidemiological evidence to date has not shown an association between pesticide exposure and aplastic anemia.[9]

Production of red blood cells can more than double in response to anemia or hypoxemia. Hematopoiesis also requires an adequate supply of minerals (for example, iron, cobalt and copper) and vitamins (for example, folic acid, vitamin B12, pyridoxine, ascorbic acid and riboflavin), and deficiencies generally cause characteristic anemia, or, less often, Common failure of hematopoiesis.[10]

Analysis of complete blood tests showed that the use of pesticides for the previous three days had a significant effect on most selected health indicators, such as monocytes, percentage of monocytes, percentage of red blood cells, hemoglobin, hematocrit, average blood cell volume, average living cell hemoglobin, average concentration of red blood cell hemoglobin, variation in the coefficient of width of red blood cell distribution, platelet count, and width of platelet distribution. However, the effects of exposure to pesticides in the majority of indicators were absent (red blood cells, hemoglobin, platelet counts, etc.) after 3 days.[11]

Critical symptoms in management are respiratory symptoms. Decreased plasma pseudocholinesterase and / or red blood cells acetylcholinesterase enzyme activity are generally available biochemical indicators for excessive absorption of OP compounds (organophosphate).[12]

\section{CONCLUSION}

There was association between pesticide exposure with anemia in women farmers in Bandungan Village, Semarang District.

\section{REFERENCES}

[1] U.S Department of Health and Human Services, "Anemia Healthy Lifestyle Changes," 2011.

[2] "U.S. Department of Health \& Human Services. IronDeficiency Anemia. In: Health Topics," 2019.

[3] M. Delf dan R. Manning, Major Diagnosis Fisik, 9 ed. Jakarta: Buku Kedokteran EGC, 1996.

[4] S. Horton dan J. Ross, "The economics of iron deficiency," Food Policy, vol. 28, hal. 51-75, 2003.

[5] World Health Organization, "Global Nutrition Targets 2025 : Anaemia Policy Brief," 2014.

[6] V. Dhananjayan dan B. Ravichandran, "Occupational health risk of farmers exposed to pesticides in agricultural activities," Current Opinion in Environmental Science \& Health, vol. 4, hal. 31-37, 2018.

[7] F. M. Fishel, "Pesticides : Routes of Exposure," 2015.

[8] X. Huang et al., "Association between occupational exposures to pesticides with heterogeneous chemical structures and farmer health in china," Scientific Reports, vol. 6, no. 25190, hal. 1-7, 2016.

[9] R. P. Gallagher, W. J. Threlfall, E. Jeffries, P. R. Band, J. Spinelli, dan A. J. Coldman, "Cancer and aplastic anemia in british columbia farmers," Journal of the National Cancer Institute, vol. 72, no. 6, hal. 1311-1315, 1984.

[10] L. L. Brunton, “Goodman \& Gilman's: the pharmacological basis of therapeutics." McGraw-Hill Medical Publishing Division, United States of America, 2006.

[11] R. Hu et al., "Long- and short-term health effects of pesticide exposure: A cohort study from China," PLoS ONE, vol. 10, no. 6, hal. 1-13, 2015.

[12] M. S. Manu, V. Prashant, P. Akila, M. N. Suma, dan H. Basavanagowdappa, "A retrospective analysis of serial measurement of serum cholinesterase in acute poisoning with organophosphate compounds," Toxicology International, vol. 19, no. 3, hal. 255-259, 2012. 